\title{
Entry thresholds and actual entry and exit in local markets
}

Citation for published version (APA):

Carree, M. A., \& Dejardin, M. (2004). Entry thresholds and actual entry and exit in local markets. METEOR, Maastricht University School of Business and Economics. METEOR Research Memorandum No. 043 https://doi.org/10.26481/umamet.2004043

Document status and date:

Published: 01/01/2004

DOI:

10.26481/umamet.2004043

Document Version:

Publisher's PDF, also known as Version of record

\section{Please check the document version of this publication:}

- A submitted manuscript is the version of the article upon submission and before peer-review. There can be important differences between the submitted version and the official published version of record.

People interested in the research are advised to contact the author for the final version of the publication, or visit the DOI to the publisher's website.

- The final author version and the galley proof are versions of the publication after peer review.

- The final published version features the final layout of the paper including the volume, issue and page numbers.

Link to publication

\footnotetext{
General rights rights.

- You may freely distribute the URL identifying the publication in the public portal. please follow below link for the End User Agreement:

www.umlib.nl/taverne-license

Take down policy

If you believe that this document breaches copyright please contact us at:

repository@maastrichtuniversity.nl

providing details and we will investigate your claim.
}

Copyright and moral rights for the publications made accessible in the public portal are retained by the authors and/or other copyright owners and it is a condition of accessing publications that users recognise and abide by the legal requirements associated with these

- Users may download and print one copy of any publication from the public portal for the purpose of private study or research.

- You may not further distribute the material or use it for any profit-making activity or commercial gain

If the publication is distributed under the terms of Article $25 \mathrm{fa}$ of the Dutch Copyright Act, indicated by the "Taverne" license above, 


\title{
Entry thresholds and actual entry and exit in local markets
}

\author{
Martin Carree \\ Faculty of Economics and Business Administration \\ University of Maastricht \\ The Netherlands \\ and \\ Marcus Dejardin \\ Faculté des Sciences Economiques, Sociales et de Gestion \\ Facultés Universitaires Notre-Dame de la Paix, Namur \\ Belgium
}

Abstract

Bresnahan and Reiss (1991) derive entry thresholds (equilibrium numbers of firms) for local markets but do not investigate actual entry and exit flows. This paper investigates for thirteen Belgian retail and service industries whether markets with actual numbers of firms higher (lower) than the thresholds display exit (entry) in subsequent periods.

JEL-codes: L80, R12

Keywords: Entry, exit, entry thresholds, ordered probit

Acknowledgement: Marcus Dejardin thanks the National Bank of Belgium for financial assistance and Michel Mignolet for comments on an earlier version of the paper.

Corresponding author:

Martin Carree

Department of Organization and Strategy

Faculty of Economics and Business Administration

University of Maastricht

PO Box 616

6200 MD Maastricht

The Netherlands

Tel. +31 433884981 


\section{Introduction}

Local markets are a key characterization of many service industries like plumbers, dentists, shoe stores, flower shops or restaurants. The (equilibrium) number of firms in these local service markets will be primarily dependent upon local demand. Bresnahan and Reiss (1991), in an oft-cited article, derive and estimate their so-called entry threshold, a measure of the market size required to support a given number of firms. The entry threshold is a zero-profit equilibrium level of demand (see also Schmalensee, 1992 and Sutton, 1991) which can be estimated using ordered probit analysis. Although the title of their article "Entry and Competition in Concentrated Markets” would suggest differently, their article does not consider actual entry into markets, nor exit. The current paper investigates whether markets that have less firms than the entry threshold show (net) entry of firms in the subsequent period and markets that have more firms than this threshold show (net) exit of firms.

Bresnahan and Reiss remark that more complete data on entry and exit (in local markets) is required to investigate the timing of entry and exit decisions. This is important to progress from an essentially static cross-sectional framework as developed by Bresnahan and Reiss towards a dynamic framework of entry and exit adjusting for market disequilibria. We have compiled a dataset for a range of carefully selected service industries in the 455 local regions (municipalities) of Belgium with less than 20,000 inhabitants. These data include number of firms, entry, exit and factors determining market size. The analysis suggests that the entry rate is much more flexible and more important in the adjustment process towards market equilibrium than the exit rate.

\section{Entry thresholds from ordered probit analysis}

This research deviates from earlier research, like Asplund and Sandin (1999), Brenahan and Reiss and Serra et al. (1999), to empirically examine local entry and exit rates. Number of entries, exits and incumbents are obtained for all 455 Belgian municipalities whose local market size (measured by population) is less than 20,000 (source: Belgian National Institute of Statistics). ${ }^{1}$ The data are derived from the stock of active taxable firms and self-employed (in the value-added-tax books) at the end of each year, as well as the number of registrations and deletions per year, from 1998 to 2001. Explanatory variables include: population and personal income per capita in 1998; net number of commuters (commuting 'in' minus 'out')

\footnotetext{
${ }^{1}$ One municipality, Herstappe, with 84 inhabitants, was left out from the analyses.
} 
according to the 1991 census and population growth from 1990 to 1998 . There are three dummy variables: a Flanders dummy (1 if Flanders; 0, otherwise); a City dummy for the presence of a city with more than 20,000 inhabitants less than ten kilometers away; and a Border dummy ( 1 if the municipality is on the border of a neighboring foreign country; 0 , otherwise).

Special attention was paid to select retail and consumer service industries that are composed of firms with similar economic activities. We opted for an industrial definition according to five-digits NACE-Belgium. The industries are selected to have their firms dependent upon local market conditions and to be commonly present in local markets (municipalities). That is, industries with a large majority of municipalities with zero firms are left out of consideration. In addition, we have selected industries that are only limitedly confronted with competition from supermarkets and department stores. The following 13 industries (NACE-Belgium code) were found to fulfill these conditions best: Plumbing (45330), Painting (45441), Butcheries (52220), Bakeries (52240, 15812; retail sale and craftsmen of bread and confectionery), Pharmacies (52310), Clothing (52421-52424), Shoe stores (52431), Flower shops (52483), Jewelry (52484), Restaurants (55301), Fast food outlets (55302), Caterers (55522) and Real estate agencies (70311).

Summary statistics of the number of incumbents (in 1998), entrants and exits are presented in Table 1. For entry and exit we provide data both for 1999 and for the three-year period 19992001. The average number of incumbents per municipality range from 1.64 for jewelry and 2.29 for shoe stores to 9.76 for fast food and 10.18 for restaurants. The average number of entrants and exits are both lowest for jewelry and both highest for fast food. Net entry is positive for five out of 13 industries (plumbing, painting, caterers, restaurants, real estate). In none of the retail industries we find a positive net entry. The fast food has the strongest growth in number of firms, with the butcheries and bakeries the strongest decline. Industries with relatively high (low) entry rates also have relatively high (low) exit rates. The distribution of municipalities in our sample according to population size is given in Figure 1.

[Table 1 and Figure 1 about here]

The entry threshold $N_{t}^{*}$ in year $t$ is computed using an ordered probit analysis since the threshold only takes integer values (starting at 0 ). The entry threshold is assumed to depend upon six exogenous variables. These are personal income per capita (PersInc), rate of 
commuting, viz. net number of commuters per capita (Commute), population growth rate (PopGr) and Flanders, City and Border dummies as introduced earlier. In the ordered probit regression these variables are all multiplied with population (Pop) as in Bresnahan and Reiss (1991, p.979). Population and average personal income are included as key determinants of market size. We correct for the rate of commuting since many commuters may buy goods in the municipality where they work. We introduce a Flanders dummy to correct for potential regional differences in tastes (Belgium consists of three main regions: Flanders, Brussels and Wallonia with the latter two (predominantly) French-speaking). The City dummy is used to correct for demand effects of the presence of a large city nearby. The Border dummy corrects for possible demand effects of a municipality being on the border of France, Luxembourg, Germany or the Netherlands. The (latent) variable $N_{t}^{*}$ is determined as:

$$
N_{t}^{*}=\left(\alpha_{0}+\alpha_{1} \text { PersInc }_{t}+\alpha_{2} \text { Commute }_{t}+\alpha_{3} \text { PopGr }_{t}+\alpha_{4} \text { Flanders }+\alpha_{5} \text { City }_{t}+\alpha_{6} \text { Border }^{*} \text { Pop }_{t}\right.
$$

The number of firms in a municipality is determined from $N_{t}^{*}$ as follows:

$$
N_{t}=\left\{\begin{array}{ccc}
0 & \text { if } & N_{t}^{*} \leq \gamma_{1} \\
1 & \text { if } & \gamma_{1}<N_{t}^{*} \leq \gamma_{2} \\
\vdots & \vdots & \\
M & \text { if } & \gamma_{M}<N_{t}^{*}
\end{array}\right.
$$

The ordered probit maximum likelihood routine (Stata 8.0) renders estimates for the parameters $\alpha_{0}$ through $\alpha_{6}$ and the threshold values $\gamma_{1}$ through $\gamma_{M}$. The estimates for the parameters for each of the thirteen industries are presented in Table 2. The fit of the ordered probit model is relatively constant over the different industries. The average pseudo $\mathrm{R}^{2}$ for the thirteen industries is 0.1540 . It ranges for a minimum of 0.1025 for caterers to a maximum of 0.2058 for bakeries.

The effect of personal income is significant for eight industries. Five times a significant positive effect is found: for plumbing, pharmacies, clothing, restaurants and real estate. ${ }^{2}$ It is significantly negative for butcheries, bakeries and fast food. The first two industries have suffered from hypermarkets introduced in the areas with most buying power. One can

\footnotetext{
${ }^{2}$ The jewelry industry does not have a significant positive effect. This surprising outcome may be the result of most consumers buying jewelries in a nearby town. This is confirmed by the effects of the rate of commuting and the City dummy.
} 
juxtapose the negative effect for fast food to the positive effect for restaurants (serving traditional food). Fast food is a relatively cheap way of eating out. The effect of the rate of commuting is significant for seven industries, the majority of which positive. A positive effect is as expected since a positive net rate of commuting implies increased buying power. The effect of population growth (in the previous periods) is significant for eight industries. It is negative for butcheries, bakeries and flower shops. Cities in which population declines or is stagnant are likely to have a relatively high percentage of elderly. These are probably more likely to buy in the traditional butcheries and bakeries. The effect of population growth is very strong for the fast food and real estate industries. Those profit probably from a relatively young population. The Flanders dummy is significant for eight industries and only one is negative (pharmacies). The positive effect could be due to Flemish families having more financial means next to personal income or it could be due to a range of other cultural factors. The City dummy is eight times significant and only for plumbing there is a positive effect. Hence, in general shops in small municipalities suffer from the presence of larger cities nearby. The Border dummy is only significant for four industries and all of these effects are negative.

[Table 2 about here]

\section{Entry and exit adjusting for disequilibrium}

For each of the industries in Table 2 we computed the predicted number of firms in a

municipality, $\hat{N}_{t}$. This is used to compute the market 'disequilibrium': the difference between the predicted and actual number of firms, $\hat{N}_{t}-N_{t}$. A positive difference indicates 'market room' for new entry, while a negative difference indicates lack of 'market room'. Entrepreneurs who are alert to profit opportunities are more likely to enter local markets with considerable 'market room' when compared to more saturated markets. Entrepreneurs in crowded local markets (who make losses) are more likely to leave than entrepreneurs in unsaturated markets, maybe to enter other more promising local markets. Hence, we expect that local markets in which the predicted number of firms exceeds the actual number to show higher entry rates, lower exit rates and, consequently, higher net entry rates than local markets in which the actual number exceeds the predicted number. 
In Table 3 we test this by means of regressions of the number of entrants in period $t, E_{t}$, the number of exiting firms in period $t, X_{t}$, and the difference (net entry), $E_{t}-X_{t}$, on the preceding 'market room' variable $\hat{N}_{t-1}-N_{t-1}$ and on the preceding stock of firms $N_{t-1}$. The period $t-1$ is always 1998. The results for period $t$ are given for 1999 (one-year reaction) and 1999-2001 (three-year reaction). ${ }^{3}$

\section{[Table 3 about here]}

The results clearly indicate that entry is indeed positively affected by 'market room'. Nine out of 13 industries have a significant positive effect and none of the industries have a negative effect in case the year 1999 is chosen. In case the three-year period 1999-2001 is chosen, all thirteen industries show a significant positive effect. The results for exit are quite different. For the year 1999 there are only two industries showing a significant effect, one positive (restaurants) and only one the expected negative effect (butcheries). For the years 1999-2001 there are five industries with a significant effect, but each of them positive. However, the results for entry are stronger than those found for exit, resulting in most industries to have a positive effect for net entry. The one exception is Bakeries. ${ }^{4}$

The results suggest that net entry indeed adjusts for disequilibrium. For four industries (Painting, Pharmacies, Flowers, Caterers) this adjustment is more than $10 \%$ for a three-year period. However, for other industries this adjustment can be more modest. The results also indicate that the adjustment for disequilibrium mainly takes places through differences in entry rates between municipalities.5 This suggests that when the actual number of firms is higher than the available 'market room', a negative net entry rate is caused by a lower entry rate rather than by a higher exit rate.

\footnotetext{
${ }^{3}$ We also computed these results in case of using a backward stepwise ordered probit regression as the first step. All results concerning significance effects were confirmed. Regression analysis instead of a count data method is chosen as the second step because net entry can be negative and has no natural lower limit. Unreported Poissontype analyses give qualitatively similar results and are available upon request.

${ }^{4}$ The unexpected effect of market disequilibrium for Bakeries led us to a further investigation of this industry. An official of the Belgian Confederation of the Bakery, Pastry, Chocolate and Ice-Cream industry suggested that the growing number of bakeries selling their products through multiple locations - breaking the traditional one producer - one selling point relationship could account for this. This type of restructuring was taking place mostly in cities. We have tested the assumption that the effect of market room on net entry was dependent upon municipality population size. We found indeed that the negative effect is strongest for the municipalities with most inhabitants in our sample.

${ }^{5}$ This confirms earlier findings in Carree and Thurik (1999).
} 


\section{Conclusion}

We derive a relationship between local market size and number of firms for thirteen different Belgian retail and service industries (in 1998) using ordered probit analysis. We investigate whether markets that have higher (lower) actual than predicted numbers of firms show exit (entry) in subsequent periods of one and three years. The results confirm that over a threeyear period the rate of (net) entry is positively affected by the presence of market 'room'. The exit rate, however, does not show a negative relation with market 'room'. This indicates that changes in entry rates are a more likely source of adjusting for market disequilibria than changes in exit rates. The speed of adjustment is relatively low for most industries, however.

\section{References}

Asplund, M. and R. Sandin (1999), The number of firms and production capacity in relation to market size, Journal of Industrial Economics 47, 69-85.

Bresnahan, T.F. and P.C. Reiss (1991), Entry and competition in concentrated markets, Journal of Political Economy 99, 977-1009.

Carree, M.A. and A.R. Thurik (1999), The carrying capacity and entry and exit flows in retailing, International Journal of Industrial Organization 17, 985-1007.

Schmalensee, R. (1992), Sunk costs and market structure: A review article, Journal of Industrial Economics 40, 125-134.

Serra, D., C. ReVelle and K. Rosing (1999), Surviving in a competitive spatial market : The threshold capture model, Journal of Regional Science 39, 637-652

Sutton, J. (1991), Sunk Costs and Market Structure, Cambridge: MIT Press. 
Table 1: Summary statistics: Averages across municipalities

$\begin{array}{lcllll}\text { Industry } & \text { Stock98 } & \text { Entry99 } & \text { Exit99 } & \text { Entry99-01 Exit99-01 } \\ \text { Plumbing } & 9.35(32) & 0.55(4) & 0.49(4) & 1.66(7) & 1.57(7) \\ \text { Painting } & 4.75(19) & 0.30(4) & 0.29(4) & 0.95(7) & 0.89(6) \\ \text { Butcheries } & 6.51(28) & 0.26(3) & 0.43(5) & 0.65(6) & 1.39(12) \\ \text { Bakeries } & 9.42(67) & 0.51(4) & 0.76(5) & 1.52(7) & 2.18(9) \\ \text { Pharmacies } & 4.54(23) & 0.22(3) & 0.23(4) & 0.56(4) & 0.68(6) \\ \text { Clothing } & 5.73(54) & 0.41(5) & 0.49(6) & 1.21(8) & 1.40(14) \\ \text { Shoe stores } & 2.29(13) & 0.13(2) & 0.20(3) & 0.39(3) & 0.59(6) \\ \text { Flower shops } & 4.64(19) & 0.32(3) & 0.34(3) & 0.87(5) & 0.96(7) \\ \text { Jewelry } & 1.64(10) & 0.06(2) & 0.11(2) & 0.18(3) & 0.30(3) \\ \text { Restaurants } & 10.18(91) & 0.91(9) & 0.74(8) & 2.71(22) & 2.24(20) \\ \text { Fast food } & 9.76(80) & 1.13(6) & 1.16(9) & 3.33(23) & 3.33(25) \\ \text { Caterers } & 3.24(13) & 0.28(3) & 0.23(4) & 0.81(4) & 0.71(6) \\ \text { Real estate } & 4.70(62) & 0.40(5) & 0.32(4) & 1.19(13) & 0.96(9)\end{array}$

Note: The maximum number of firms across municipalities per category is given between brackets. The minimum number is always zero.

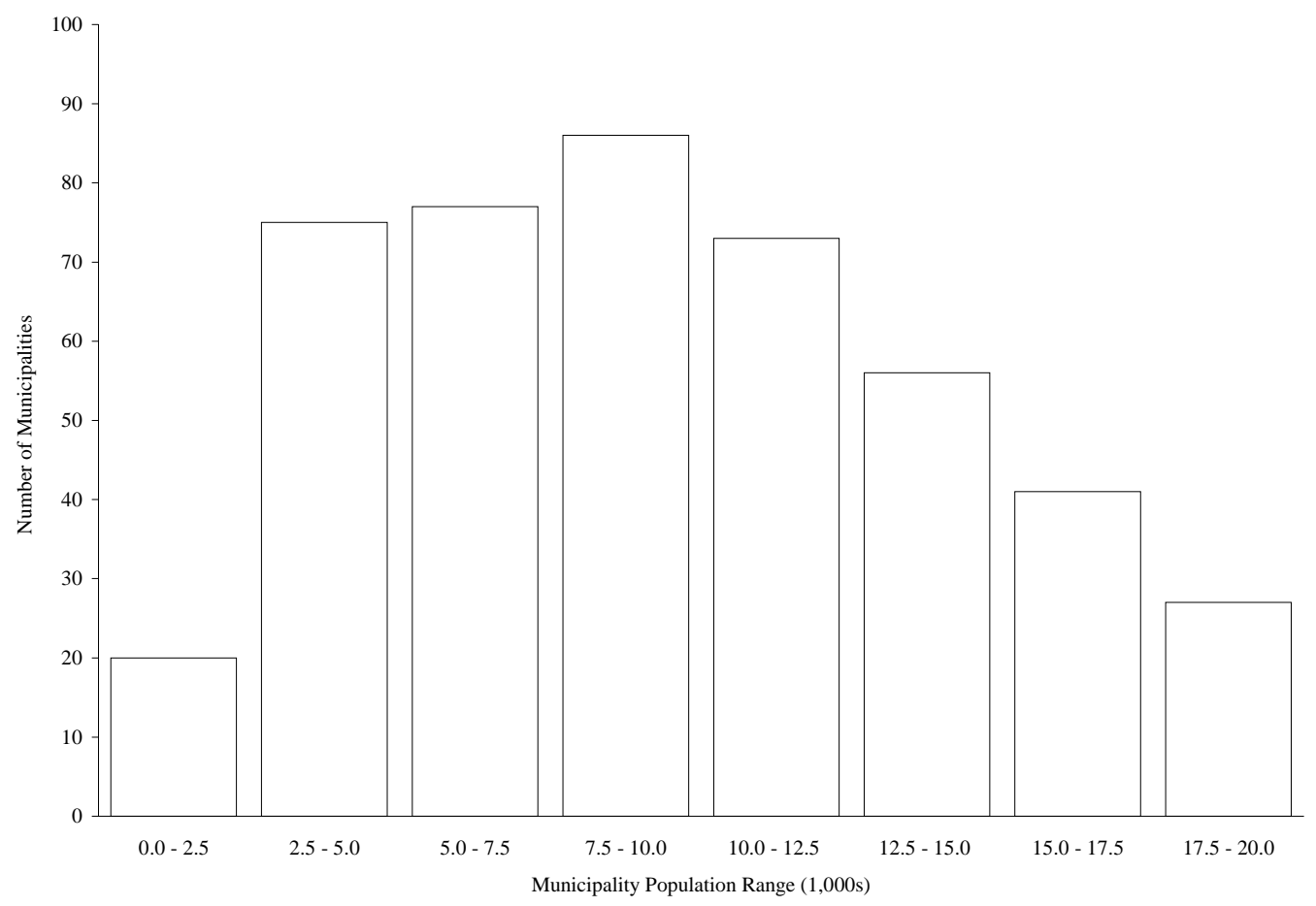

Figure 1: Distribution of municipalities according to population size 
Table 2: Ordered probit regression results (all multiplied with population)

\begin{tabular}{|c|c|c|c|c|c|c|c|}
\hline Industry & const & PersInc & Commute & PopGr & Flanders & City & Border \\
\hline Plumbing & $\begin{array}{l}0.148^{* * *} \\
(0.041)\end{array}$ & $\begin{array}{c}0.218 * * \\
(0.099)\end{array}$ & $\begin{array}{l}-0.008 \\
(0.051)\end{array}$ & $\begin{array}{l}0.391 * * * \\
(0.136)\end{array}$ & $\begin{array}{l}-0.015 \\
(0.011)\end{array}$ & $\begin{array}{l}0.037 * * * \\
(0.012)\end{array}$ & $\begin{array}{c}0.012 \\
(0.013)\end{array}$ \\
\hline Painting & $\begin{array}{l}0.234 * * * \\
(0.041)\end{array}$ & $\begin{array}{l}-0.126 \\
(0.098)\end{array}$ & $\begin{array}{c}0.049 \\
(0.051)\end{array}$ & $\begin{array}{c}0.034 \\
(0.136)\end{array}$ & $\begin{array}{l}0.031^{* * *} \\
(0.011)\end{array}$ & $\begin{array}{l}-0.029 * * \\
(0.012)\end{array}$ & $\begin{array}{l}-0.020 \\
(0.013)\end{array}$ \\
\hline Butcheries & $\begin{array}{l}0.409 * * * \\
(0.043)\end{array}$ & $\begin{array}{l}-0.486 * * * \\
(0.100)\end{array}$ & $\begin{array}{l}-0.085^{*} \\
(0.051)\end{array}$ & $\begin{array}{l}-0.481^{* * *} \\
(0.137)\end{array}$ & $\begin{array}{l}0.061^{\text {*** }} \\
(0.011)\end{array}$ & $\begin{array}{l}-0.034^{* * *} \\
(0.012)\end{array}$ & $\begin{array}{l}-0.017 \\
(0.013)\end{array}$ \\
\hline Bakeries & $\begin{array}{l}0.574 * * * \\
(0.045)\end{array}$ & $\begin{array}{l}-0.560 * * * \\
(0.100)\end{array}$ & & $\begin{array}{l}-0.278 * * \\
(0.137)\end{array}$ & $\begin{array}{l}0.054^{* * *} \\
(0.011)\end{array}$ & $\begin{array}{l}-0.044 * * * \\
(0.012)\end{array}$ & $\begin{array}{l}-0.025 * \\
(0.013)\end{array}$ \\
\hline Pharmacies & $\begin{array}{c}\text { s } 0.127 * * * \\
(0.041)\end{array}$ & $\begin{array}{l}0.419^{* * *} \\
(0.102)\end{array}$ & $\begin{array}{l}-0.128^{* *} \\
(0.052)\end{array}$ & $\begin{array}{l}-0.130 \\
(0.138)\end{array}$ & $\begin{array}{l}-0.052^{* * *} \\
(0.011)\end{array}$ & $\begin{array}{l}-0.015 \\
(0.012)\end{array}$ & $\begin{array}{l}-0.028^{* *} \\
(0.013)\end{array}$ \\
\hline Clothing & $\begin{array}{l}0.195^{* * *} \\
(0.041)\end{array}$ & $\begin{array}{l}0.236 * * \\
(0.099)\end{array}$ & $\begin{array}{l}0.237 * * * \\
(0.053)\end{array}$ & & $\begin{array}{l}0.033^{* * *} \\
(0.011)\end{array}$ & $\begin{array}{l}-0.051^{* * *} \\
(0.012)\end{array}$ & $\begin{array}{l}-0.017 \\
(0.013)\end{array}$ \\
\hline Shoe stores & $\begin{array}{l}\text { s } 0.271^{* * *} \\
(0.042)\end{array}$ & $\begin{array}{l}-0.109 \\
(0.101)\end{array}$ & $\begin{array}{l}0.152^{* * * *} \\
(0.053)\end{array}$ & $\begin{array}{l}-0.178 \\
(0.140)\end{array}$ & $\begin{array}{l}0.031 * * * \\
(0.011)\end{array}$ & $\begin{array}{l}-0.041 * * * \\
(0.013)\end{array}$ & $\begin{array}{l}-0.016 \\
(0.013)\end{array}$ \\
\hline Flowers & $\begin{array}{l}0.262 * * * \\
(0.042)\end{array}$ & $\begin{array}{l}-0.006 \\
(0.099)\end{array}$ & $\begin{array}{l}-0.064 \\
(0.052)\end{array}$ & & $\begin{array}{l}0.030^{* * *} \\
(0.011)\end{array}$ & & $\begin{array}{l}-0.000 \\
(0.013)\end{array}$ \\
\hline Jewelry & $\begin{array}{l}0.229 * * * \\
(0.042)\end{array}$ & $\begin{array}{c}0.009 \\
(0.101)\end{array}$ & $\begin{array}{l}0.195^{* * *} \\
(0.054)\end{array}$ & $\begin{array}{l}-0.142 \\
(0.141)\end{array}$ & $\begin{array}{l}-0.006 \\
(0.011)\end{array}$ & $\begin{array}{l}-0.037 * * * \\
(0.013)\end{array}$ & $\begin{array}{l}-0.019 \\
(0.013)\end{array}$ \\
\hline Restaurants & $\begin{array}{l}\text { s } 0.180^{* * * *} \\
(0.040)\end{array}$ & $\begin{array}{l}0.195 * * \\
(0.098)\end{array}$ & $\begin{array}{l}0.204^{* * *} \\
(0.052)\end{array}$ & $\begin{array}{r}0.233^{*} \\
(0.136)\end{array}$ & $\begin{array}{c}0.005 \\
(0.010)\end{array}$ & $\begin{array}{l}-0.054^{* * * *} \\
(0.012)\end{array}$ & $\begin{array}{l}-0.001 \\
(0.013)\end{array}$ \\
\hline Fast food & $\begin{array}{l}0.401^{* * * *} \\
(0.042)\end{array}$ & $\begin{array}{l}-0.289 * * * \\
(0.099)\end{array}$ & $\begin{array}{c}0.065 \\
(0.051)\end{array}$ & $\begin{array}{l}0.684^{* * * *} \\
(0.138)\end{array}$ & $\begin{array}{l}0.038^{* * *} \\
(0.011)\end{array}$ & $\begin{array}{l}-0.010 \\
(0.012)\end{array}$ & $\begin{array}{c}0.006 \\
(0.013)\end{array}$ \\
\hline Caterers & $\begin{array}{l}0.114^{* * * *} \\
(0.041)\end{array}$ & $\begin{array}{c}0.134 \\
(0.099)\end{array}$ & $\begin{array}{c}0.007 \\
(0.052)\end{array}$ & $\begin{array}{l}0.303^{* *} \\
(0.138)\end{array}$ & $\begin{array}{l}-0.008 \\
(0.011)\end{array}$ & $\begin{array}{l}-0.012 \\
(0.012)\end{array}$ & $\begin{array}{l}-0.030 * * \\
(0.013)\end{array}$ \\
\hline Real estat & $\begin{array}{l}-0.096 * * \\
(0.041)\end{array}$ & $\begin{array}{l}0.714^{* * * *} \\
(0.102)\end{array}$ & $\begin{array}{l}0.114^{* *} \\
(0.052)\end{array}$ & $\begin{array}{l}0.540^{* * * *} \\
(0.138)\end{array}$ & $\begin{array}{l}-0.016 \\
(0.011)\end{array}$ & $\begin{array}{l}-0.008 \\
(0.012)\end{array}$ & $\begin{array}{l}-0.030 * * \\
(0.013)\end{array}$ \\
\hline
\end{tabular}

Note: ${ }^{* * *},{ }^{* *}$ and $*$ mean significant at the $1 \%, 5 \%$ and $10 \%$ significance levels, respectively. The exogenous variables are presented in columns. 
Table 3: Regression results for entry, exit and net entry adjusting for disequilibrium

$\begin{array}{lclllll}\text { Industry } & \text { Ent99 } & \text { Exit99 } & \text { NE99 } & \text { Ent9901 } & \text { Exit9901 } & \text { NE9901 } \\ \text { Plumbing } & 0.015 & 0.007 & 0.007 & 0.064^{* * *} & 0.041^{* *} & 0.023 \\ & (0.013) & (0.011) & (0.016) & (0.021) & (0.020) & (0.026) \\ \text { Painting } & 0.053^{* * *} & -0.015 & 0.068^{* * *} & 0.153^{* * *} & 0.043^{*} & 0.111^{* * *} \\ & (0.016) & (0.014) & (0.020) & (0.029) & (0.024) & (0.033) \\ \text { Butcheries } & 0.018^{*} & -0.027^{*} & 0.045^{* * *} & 0.044^{* *} & -0.007 & 0.051^{* *} \\ & (0.010) & (0.013) & (0.014) & (0.018) & (0.022) & (0.023) \\ \text { Bakeries } & 0.015 & 0.015 & -0.000 & 0.043^{* *} & 0.080^{* * *} & -0.037^{*} \\ & (0.010) & (0.012) & (0.013) & (0.017) & (0.021) & (0.022) \\ \text { Pharmacies } & 0.075^{* * *} & 0.019 & 0.056^{* * *} & 0.110^{* * *} & -0.002 & 0.112^{* * *} \\ & (0.015) & (0.016) & (0.018) & (0.023) & (0.025) & (0.026) \\ \text { Clothing } & 0.020^{*} & 0.009 & 0.010 & 0.080^{* * *} & -0.007 & 0.088^{* * *} \\ & (0.010) & (0.010) & (0.013) & (0.018) & (0.015) & (0.022) \\ \text { Shoe stores } & 0.029^{*} & -0.008 & 0.036 & 0.090^{* * *} & -0.001 & 0.091^{* *} \\ & (0.016) & (0.019) & (0.022) & (0.027) & (0.031) & (0.036) \\ \text { Flowers } & 0.047^{* * *} & -0.012 & 0.058^{* * *} & 0.114^{* * *} & -0.001 & 0.115^{* * *} \\ & (0.015) & (0.016) & (0.020) & (0.026) & (0.026) & (0.031) \\ \text { Jewelry } & 0.014 & -0.012 & 0.026 & 0.073^{* * *} & 0.046 * & 0.027 \\ & (0.013) & (0.017) & (0.021) & (0.024) & (0.026) & (0.033) \\ \text { Restaurants } & 0.001 & 0.027 * * * & -0.025^{* *} & 0.033^{* *} & 0.025^{* *} & 0.008 \\ & (0.008) & (0.007) & (0.010) & (0.014) & (0.013) & (0.017) \\ \text { Fast food } & 0.019 * * & -0.009 & 0.028^{* *} & 0.073^{* * *} & 0.014 & 0.058^{* * *} \\ & (0.010) & (0.009) & (0.012) & (0.019) & (0.017) & (0.019) \\ \text { Caterers } & 0.069^{* * *} & -0.009 & 0.078^{* * *} & 0.182^{* * *} & 0.050 & 0.132^{* * *} \\ \text { Real estate } & (0.020) & (0.018) & (0.027) & (0.034) & (0.033) & (0.044) \\ & 0.014^{*} & 0.001 & 0.013 & 0.056^{* * *} & 0.016 & 0.040^{* *} \\ \text { Average } \mathrm{R}^{2} & (0.009) & (0.008) & (0.012) & (0.017) & (0.013) & (0.020) \\ & & & & & & \\ & 0.1393 & 0.2031 & 0.0357 & 0.2666 & 0.4149 & 0.0812 \\ & & & & & & \end{array}$

Note: ${ }^{* * *}, * *$ and $*$ mean significant at the $1 \%, 5 \%$ and $10 \%$ significance levels, respectively. Ent99 is entry in 1999; Exit99 is exit in 1999; NE99 is net entry in 1999; Ent9901 is entry in the years 19992001; Exit9901 is exit in the years 1999-2001; NE9901 is net entry in the years 1999-2001. 